\title{
Transportation Policy In Sustainable Development Perspectives (Study of Transportation Development in Surabaya City)
}

\author{
Sapto Pramono \\ saptopramono62@yahoo.com \\ University of Brawijaya
}

\begin{abstract}
Development of transportation in the city of Surabaya is very dependent on the implementation of public policies carried out by the Surabaya City government, because improper implementation will not get the support of the citizens or be rejected by the citizens. The implementation of transportation policy was once rejected by residents, namely when the city government wanted to make the city center toll, because according to the government the city center toll would solve the transportation problem. For this reason with the advice of consultants, the city government transferred the city center toll program to Midle East Ring Road (MERR) and Frontage Road. With these two infrastructure development programs, it is expected that transportation development can be accepted by the citizens of Surabaya City. The construction and development of this infrastructure is a long-term development or sustainable development, thus involving regulations from the central government, the East Java provincial government and the Surabaya City government.
\end{abstract}

Keywords: Surabaya City, Transportation, Implementation of Public Policy, Sustainable Development.

\section{Introduction}

The issue of the current and future transportation system development policy is how each country plays its role in the frame of a sustainable transportation system. The idea of developing sustainable transportation is an essential part of the problem of sustainable development, experience in various countries shows that building the necessary infrastructure is not always the best solution. Every construction of transportation infrastructure has environmental impacts, but the region has certain environmental capacity limits to receive the impacts that arise. In addition, the construction of the road network, especially those that only follow the demands of needs, tends to encourage the inefficient use of private vehicles. The growth of transportation needs (demand) needs to be controlled so that they are balanced with the ability to supply networks and environmental constraints.

Every development must bring environmental impacts as well as the construction of transportation infrastructure. That the community is an environmental problem and a change, for that how can the community be accepted between the various changes that exist. Thus the constraints and challenges in development will be experienced by all countries, as well as the development of transportation infrastructure in both developed and developing countries.

\section{Methods}

This research was conducted from May 2018 to June 2018, the research was conducted in two places, namely around Midle East Ring Road and frontage road, Ahmad Yani Street, Surabaya City.This research is included in the type of descriptive and qualitative research, qualitative research nature of research tends to be concerned with meaning, the strength of the qualitative paradigm lies in inductive and grounded, which is not in line with structured approaches or designs. The data used 
are primary and secondary data which are then processed and presented in narration, graphics and images. The study began with the identification of problems due to the implementation of transportation policies, then continued with the identification of problems with the development of transportation infrastructure. The operational definition of the variables of the research is based on the discussion of transportation infrastructure, namely the construction of the Middle East Ring Road (MERR) and frontage road, the next explanation is through the vehicle calculation table passing at MERR and frontage road.

Qualitative research (including historical and descriptive research) is research that does not use mathematical, statistical or computer models. In qualitative research, the data analysis model has four steps in outline. The analysis model is described as follows: conducting domain analysis, carrying out taxonomic analysis, carrying out compound analysis, and analyzing cultural themes[1].

\section{Results}

\subsection{Geographic and Demographic Conditions}

The city of Surabaya as the capital of East Java Province is located on the north coast of East Java Province or precisely located between $7^{\circ} 9^{\prime}-7^{\circ} 21$ 'South Latitude and $112^{\circ} 36^{\prime}-112^{\circ} 54$ 'East Longitude. The area is bordered by the Madura Strait in the North and East, Sidoarjo Regency in the South and Gresik Regency in the West. Topographically, most (25,919.04 Ha) are lowland with an altitude of 3-6 meters above sea level at a slope of less than 3 percent, partly at the west (12.77 percent) and south (6.52 percent) is a sloping hilly area with a height of 25-50 meters above sea level and at a slope of 5-15 percent. The rock types consist of 4 types which are basically clay or sand units.

While the type of soil, mostly in the form of alluvial soil, the rest of the soil with high lime content (hilly area). As in other tropical regions, Surabaya knows 2 seasons, rainy and dry seasons. Average rainfall is $172 \mathrm{~mm}$, with temperatures ranging from a maximum of $30^{\circ} \mathrm{C}$ and a minimum of $25^{\circ}$ C. Geographically, the city of Surabaya is located downstream of a Brantas watershed that empties into the Madura Strait. Several large rivers that function to carry and channel floods from upstream flow through the city of Surabaya, including Kali Surabaya (River of Surabaya)with Q average $=26.70 \mathrm{~m} 3 /$ second, Kali Mas with Q averaging $=6.26 \mathrm{~m} 3 / \mathrm{sec}$ and Kali Jagir (River of Jagir) with Qrata2 $=7.06 \mathrm{~m} 3 /$ second. As a downstream area, the city of Surabaya itself is an overflow area of water discharge from passing rivers and resulting in flooding in the rainy season. Administratively, the City of Surabaya is headed by the Mayor who also oversees the coordination of the administrative area of the sub-district headed by the Camat. The number of subdistricts in the city of Surabaya was 31 sub-districts and the number of villages was 160 villages and divided into 1and 9,271 Neighborhood Associations[2].

\subsection{Demographic Conditions}

To illustrate the demographic conditions of Surabaya City, data from the Population and Civil Registry Service, Surabaya City had a population of 2,929,528 people until the end of 2010 with a relatively balanced composition between men and women consisting of 50.18 percent Men and 49.82 percent of women. With an area of 33,048 Ha, the density of Surabaya City is 8,864 people / $\mathrm{km} 2$. When viewed based on the age structure, the population of Surabaya City is more productive, namely 35 years to 54 years or 32.98 percent of the total population, then at the age of 15 years to 34 years or 32.95 percent. Whereas the proportion of the elderly population is only 14.89 percent and the rest is the proportion of the young population or children, namely the age less than 14 years, which is 19.19 percent. For population after 2010 as shown in the following table 1. 
Table 1. Number of Population in Surabaya City

\begin{tabular}{|c|c|c|c|}
\hline Year & Male & Female & Amount \\
\hline 2008 & 1453135 & 1449372 & 2902507 \\
2009 & 1474874 & 1463351 & 2938225 \\
2010 & 1469916 & 1459612 & 2929528 \\
2011 & 1517341 & 1506980 & 3024321 \\
2012 & 1566072 & 1559504 & 3125576 \\
2013 & 1602875 & 1597579 & 3200454 \\
2014 & 1430985 & 142676 & 2853661 \\
2015 & 1473640 & 1469888 & 2943528 \\
2016 & 1507474 & 1509179 & 3016653 \\
\hline
\end{tabular}

Source: 2017 Surabaya City Population Registration and Civil Registration Service

\subsection{Transportation Conditions}

The general condition of traffic in the city of Surabaya is almost the same asother big cities in Indonesia. The growth of motorized vehicles, especially motorbikes, is very high, causing traffic jams that often occur on some roads in the city of Surabaya. From the transportation data of the City of Surabaya from 2010 the growth rate of motorcycle users is 10-13 percent per year. In addition to traffic jams, the other impacts that follow are air pollution. The issue of congestion in the city of Surabaya is not only caused by the high rate of growth of vehicles, but several other things that play a role are the low level of public transport services so that private vehicle users are reluctant to switch modes using public transport, lack of integration between modes of transportation due to the lack of optimal facilities transfer mode and existing transportation nodes, regional accessibility that is not optimal because there are still road networks that have not been fully formed, there are no restrictions on private vehicles, there are still centers of primary and secondary activities in certain areas that cause attraction the big one, the use of the road beyond its function and the insignificant increase in road capacity.

The road network system in the city of Surabaya forms a grade pattern with primary and secondary growth centers currently scattered in the corridors of the North and South and East and West Cities. The length of the road in the city of Surabaya in 2010 was $1,911.34 \mathrm{~km}$ consisting of national roads, provincial roads and city roads. Regarding the current road conditions, out of a total of 11,021 roads in Surabaya, there are 9,632 roads that are still feasible, 1,374 roads that must be repaired, and 15 segments still under repair. The main problems with the road network system in Surabaya are as follows:

a. Congestion and low levels of accessibility to several areas in the city of Surabaya. Congestion problems that occur in the North-South corridor are due to the fact that the corridor is naturally formed and corridor access is perfectly connected so that the center of the primary and secondary activities is growing rapidly in this corridor area than the area connected by the East corridor West. In the East-West corridor area, Surabaya is currently growing rapidly but still not supported by perfect access to connect the two regions so that if the movement towards the East or West region must pass through the city center and eventually the traffic will accumulate on the North corridor - South City.

b. Another issue that drives the congestion problem is the presence of bottle neck roads which inhibit traffic flow and the intersection of a plot with the railroad tracks. Increasing vehicle volumes have resulted in smaller road capacity if not offset by increased network and capacity Street.

The following is a table on the condition of transportation infrastructure in the city of Surabaya from 2009 to 2015 . 
Table 2. Road Length by Surface Type, Paved Road Conditions and Road Class 2009 - 2015

\begin{tabular}{|c|c|c|c|c|c|c|c|c|c|}
\hline \multicolumn{2}{|c|}{ No } & Descriptio & 2009 & 2010 & 2011 & 2012 & 2013 & 2014 & 2015 \\
\hline \multirow[t]{6}{*}{1} & & Type of surface & & & & & & & \\
\hline & $\mathrm{a}$ & Paving & 586.00 & 142.11 & 142.37 & 196.73 & 196,73 & 197,28 & 197,00 \\
\hline & $\mathrm{b}$ & Asphalt & 835,00 & $1.284,04$ & 1284,28 & 1427,75 & 1677,98 & 1679,31 & $1.678,64$ \\
\hline & $\mathrm{c}$ & Gravel & & & & & & & \\
\hline & $\mathrm{d}$ & Soil & & & & & & & \\
\hline & & Amount & 1421,00 & 1426,15 & 1426,65 & 1624 & 1874,71 & 1876,59 & 1875,64 \\
\hline \multirow[t]{6}{*}{2} & & Road Conditions & & & & & & & \\
\hline & $\mathrm{a}$ & Good & 1207,00 & 1381,50 & 1381,95 & 1397,18 & 1647,55 & 1649,01 & 1648,28 \\
\hline & $\mathrm{b}$ & Medium & 99,47 & 15,63 & 15,63 & 4,42 & 4,40 & 4,30 & 4,35 \\
\hline & $\mathrm{c}$ & Broken & 85,26 & 26,79 & 26,79 & 25,15 & 25,03 & 25,00 & 25,01 \\
\hline & $\mathrm{d}$ & Heavy Damage & 28,42 & 2,23 & 2,23 & 1,01 & 1,00 & 1,00 & 1,00 \\
\hline & & Amount & 1421,00 & 1426,15 & 142,65 & 1426,76 & 1677,98 & 1679,31 & 1678,64 \\
\hline \multirow[t]{9}{*}{3} & & Road Class & & & & & & & \\
\hline & $\mathrm{a}$ & Primary Artery & & & & & & & \\
\hline & $\mathrm{b}$ & Secondary Artery & 225,00 & & & & & & \\
\hline & $\mathrm{c}$ & $\begin{array}{l}\text { Primary } \\
\text { Collector }\end{array}$ & 1196,00 & 20,88 & 21,12 & 222,23 & 23,30 & 24,63 & 23,96 \\
\hline & $\mathrm{d}$ & $\begin{array}{r}\text { Secondary } \\
\text { Collector } \\
\end{array}$ & & 71,80 & 71,80 & 71,80 & 71,80 & 71,80 & 71,80 \\
\hline & $\mathrm{e}$ & Local & & & & & & & \\
\hline & $\mathrm{f}$ & Special & & & & & & & \\
\hline & $\mathrm{g}$ & Not specified & & & & & & & \\
\hline & & Amount & 1421,00 & 1426,15 & 1426,65 & 1427,76 & 1677,98 & 1679,31 & 1678,64 \\
\hline
\end{tabular}

Source: 2017 Surabaya City Highways and Settlement Service

In the condition of the number of motorized vehicles still dominated by private vehicles from public vehicles, private vehicles are mainly motorbikes and cars, as in the following table:

Table 3. Number of Motor Vehicles by Type 2009 - 2015

\begin{tabular}{|l|l|l|l|l|l|l|l|l|}
\hline No & $\begin{array}{l}\text { Transportation } \\
\text { type }\end{array}$ & \multicolumn{1}{|c|}{2009} & \multicolumn{1}{|c|}{2010} & \multicolumn{1}{|c|}{2011} & 2012 & 2013 & 2014 & 2015 \\
\hline 1 & Sedan & 51.610 & 50.555 & 48.258 & 47.459 & 50.164 & 53.024 & 56.046 \\
\hline 2 & Jeep & 29.022 & 29.601 & 28.312 & 29.635 & 31.324 & 33.110 & 34.997 \\
\hline 3 & ST Wagon & 183.645 & 198.960 & 199.360 & 217.686 & 230.094 & 243.209 & 257.072 \\
\hline 4 & Bus & 2.064 & 2.279 & 2.304 & 2.486 & 2.268 & 2.777 & 2.936 \\
\hline 5 & Truck & 86.987 & 89.530 & 89.238 & 100.809 & 106.555 & 112.629 & 119.049 \\
\hline 6 & Motorcycle & 1.129 .870 & 1.213 .457 & 1.274 .660 & 1.402 .190 & 1.482 .115 & 1.566 .595 & 1.655 .891 \\
\hline 7 & $\begin{array}{l}\text { Heavy } \\
\text { equipment }\end{array}$ & 73 & 71 & 80 & 150 & 159 & 168 & 177 \\
\hline & & & & & & & & \\
\hline & Amount & 1.483 .271 & 1.584 .453 & 1.645 .212 & 1.645 .415 & 1.903 .039 & 2.011 .512 & 2.126 .168 \\
\hline
\end{tabular}

Source: Surabaya City Police Region 2017

\subsection{Field Data Results}

For primary data obtained based on surveys in the field, the data taken are vehicles that pass at certain hours, which results in traffic congestion. Likewise for research locations, is the location in accordance with the research variables, MERR and frontage road locations. The selection of two locations or locations of the study was caused by researchers wanting to know MERR and frontage road as an alternative to solve the traffic (transportation) in Surabaya.

The time to collect data is three times, namely morning, afternoon and evening / evening with the following time / hour accuracy; morning between 6:00 a.m. to 7:00 p.m., afternoon between 10:00 p.m. to 11:00 p.m. and evening / evening between 6:00 p.m. and 7 p.m. In addition, at MERR and frontage road locations the number of vehicles counted is those that pass both on the west and east.

The following is the data of Surabaya City traffic flow on 4 (four) lines, MERR west side, MERR east side, Ahmad Yani frontage road east side. The type of vehicle is classified into 5 (five0 types of vehicles, namely: 1) Public Vehicle / Yellow Plate (Passenger Transport); 2) Truck / Pick 
Up / Tank Car (Goods); 3) Private Cars; 4) Motorcycles and 5) Others (Becak, Bicycles and others). Divided into working days and weekends Saturday, Sunday and Monday. In addition, it is also divided into 3 (three) times, namely: 06.00-07.00, $10.00-11.00$ and 18.00-19.00.

Table 4. Data on the traffic flow of Surabaya City on the MERR west side.

\begin{tabular}{|c|l|c|}
\hline \multirow{2}{*}{ No } & \multicolumn{1}{|c|}{ Transportation Type } & Amount \\
& \multicolumn{1}{|c|}{} & \\
\hline 1 & Public Vehicle / Yellow Plate (Passenger ransportation) & 177 \\
\hline 2 & Truck / Pick Up / Tank Car (Goods) & 863 \\
\hline 3 & Private car & 10267 \\
\hline 4 & Motorcycle & 17997 \\
\hline 5 & Others (Becak, Bicycle, etc.) & 74 \\
\hline
\end{tabular}

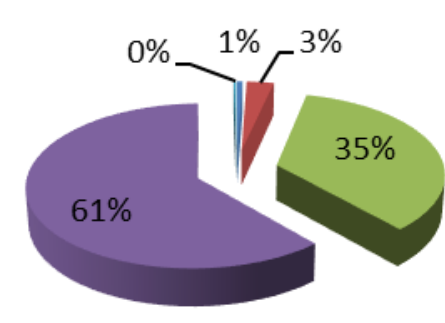

- Public Vehicle / Yellow Plate (Passenger Transportation)

- Truck / Pick Up / Tank Car (Goods)

- Private car

- Motorcycle

Others (Becak, Bicycle, etc.)

Fig.1. Data on the Traffic Flow of Surabaya City on the MERR West Side.

Table 5. Data on the traffic flow of Surabaya City on the MERR east side.

\begin{tabular}{|c|l|c|}
\hline \multirow{2}{*}{ No } & \multicolumn{1}{|c|}{ Transportation Type } & Amount \\
& \multicolumn{1}{|c|}{} & \\
\hline 1 & Public Vehicle / Yellow Plate (Passenger ransportation) & 237 \\
\hline 2 & Truck / Pick Up / Tank Car (Goods) & 864 \\
\hline 3 & Private car & 9436 \\
\hline 4 & Motorcycle & 18112 \\
\hline 5 & Others (Becak, Bicycle, etc.) & 95 \\
\hline
\end{tabular}

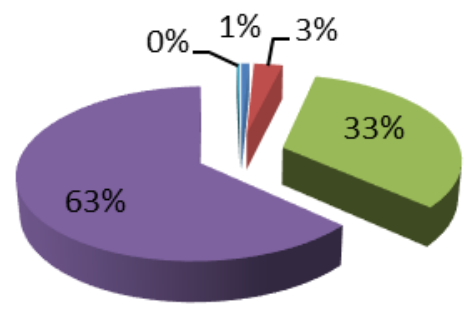

- Public Vehicle / Yellow Plate

(Passenger Transportation)

- Truck / Pick Up / Tank Car

(Goods)

- Private car

Motorcycle

- Others (Becak, Bicycle, etc.)

Fig. 2 .Data on the Traffic Flow of Surabaya City on the MERR East Side. 
Traffic users on the East Side MERR line in the table and graph above show that the user is dominated by motor vehicles of $63 \%$ or 18112 units, followed by $33 \%$ car types or 9436 vehicles. Whereas the least number of users of this line are the types of Becak, Bike, and others vehicles, less than $1 \%$ or only 95 pieces.

It can be concluded based on 2 (two) tables and graphs above shows the MERR East and West sides of the crowd in all types of vehicles are almost the same dominated by motorized vehicles that reach $61 \%-63 \%$ or $9436-10267$ pieces, followed by the type of vehicle Private cars reach $33 \%$ $35 \%$ or $9436-10267$ pieces.

Table 6. Data on the Traffic Flow of Surabaya City on the MERR East Side.

\begin{tabular}{|c|l|c|}
\hline No & \multicolumn{1}{|c|}{ Transportation Type } & Amount \\
\hline 1 & Public Vehicle / Yellow Plate (Passenger Transportation) & 1191 \\
\hline 2 & Truck / Pick Up / Tank Car (Goods) & 840 \\
\hline 3 & Private car & 12209 \\
\hline 4 & Motorcycle & 43157 \\
\hline 5 & Others (Becak, Bicycle, etc.) & 99 \\
\hline
\end{tabular}

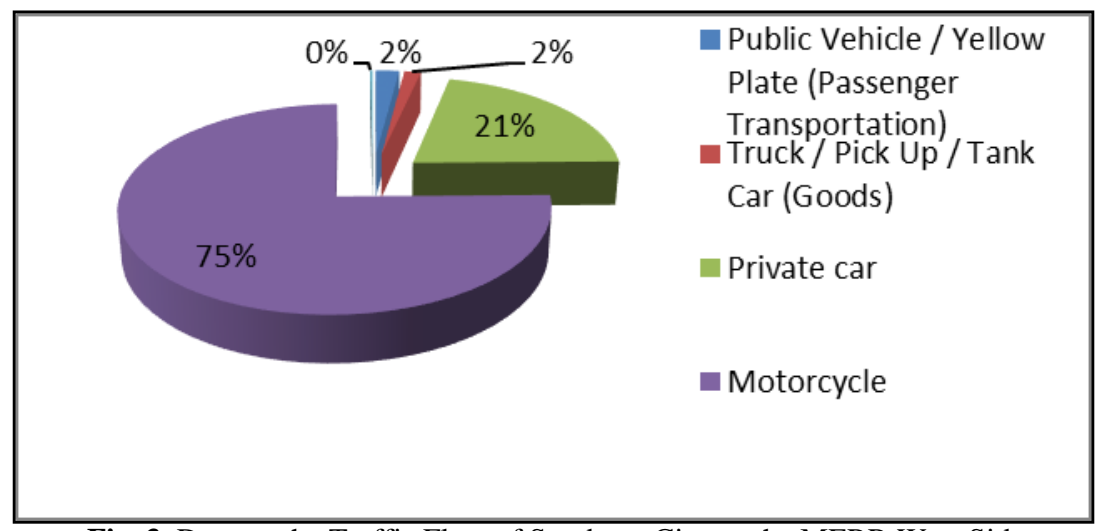

Fig. 3. Data on the Traffic Flow of Surabaya City on the MERR West Side.

In the Table and Graph above shows that most West Side Frontage users are Motorcycles as much as $75 \%$ or 43157 pieces, followed by private car types $21 \% \%$ or 12209 pieces. While the least number of users of this route are the types of Becak, Bicycles, and others vehicles less than $1 \%$ or only 99 pieces.

Table 7. Data on the Traffic Flow of Surabaya City on the Frontage Road East Side.

\begin{tabular}{|c|l|c|}
\hline No & \multicolumn{1}{|c|}{ Transportation Type } & Amount \\
\hline 1 & Public Vehicle / Yellow Plate (Passenger Transportation) & 254 \\
\hline 2 & Truck / Pick Up / Tank Car (Goods) & 292 \\
\hline 3 & Private car & 5489 \\
\hline 4 & Motorcycle & 13984 \\
\hline 5 & Others (Becak, Bicycle, etc.) & 159 \\
\hline
\end{tabular}
Source: Primary Data Processed 


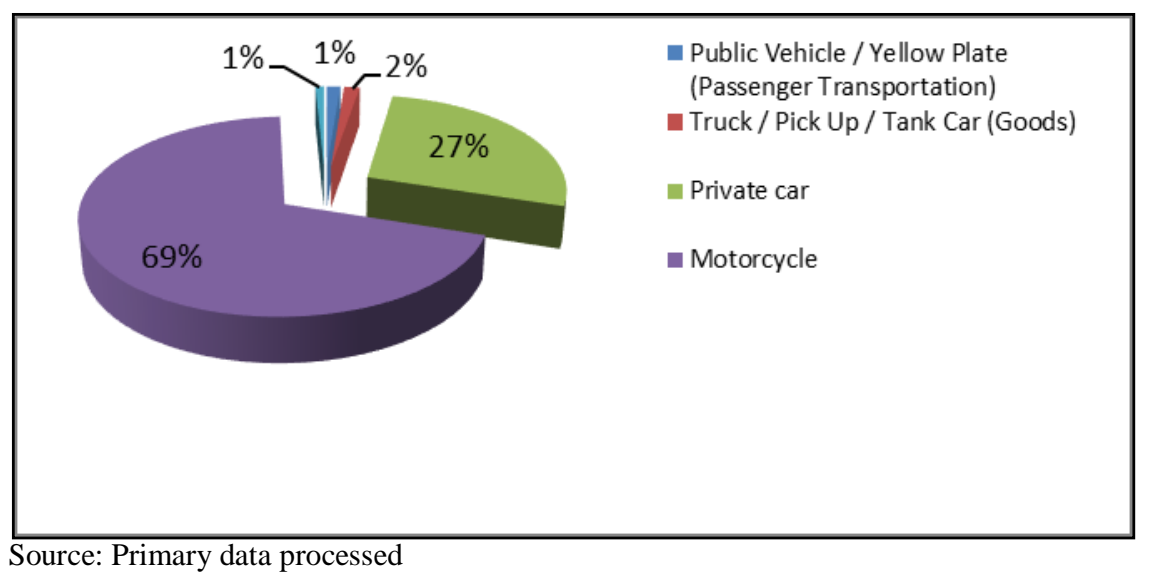

Fig. 4. Data on the Traffic Flow of Surabaya City on the Frontage East Side.

Referring to the table and graph above, it can be described that Frontage Sisi Timur users are still dominated by motor vehicles as much as $69 \%$ or 13984 pieces, followed by private car types 27 $\% \%$ or 5489 pieces. Whereas the least number of users of this line are the types of Becak, Bicycle, and others vehicles, less than $1 \%$ or only 99 pieces.

It can be concluded that the table and graph above show that the densest Frontage users are West Side Frontage more crowded than the East Side Frontage. Motor vehicle types reach $75 \%$ or 43157 pieces, while private car types reach 12209 pieces. In addition, public vehicles / yellow plates (passenger transportation) are also the most populous on the West Side Frontage. On all MERR lines and the most dense frontage is the West Side Frontage.

\subsection{Interview Result}

To support this research, interviews were conducted with several related parties, both from the Surabaya City Government, members of the Surabaya Regional People's Representative Council and regional and city governance experts from the Sepuluh November Institute of Technology Surabaya. Interviews were also conducted with several residents of frontage road and MERR users, the results of interviews with various related parties and residents were as follows:

a. According to Mr. Beta (Head of Traffic Section of the Transportation Office), the agency has a role to support by carrying out traffic management and engineering, also providing public transportation especially those that are mass as a means to overcome traffic congestion.

b. According to Mrs. Nurul, (staff of the Surabaya City Development Planning Agency-) that institution is an element of government administration planning that carries out tasks and coordinates the preparation, control and evaluation of the implementation of regional development plans. As the coordinator of the development planning development, that institution develops activities stages that involve various stakeholders in it, in order to utilize and allocate existing resources, as well as to improve social welfare.

c. One of the staff from the Public Works service, namely Mrs. Warsini, that with the development and development of MERR and frontage road, the PU service has a goal: to add alternative road sections in Surabaya City, to realize an even road network in Surabaya City, to add alternative roads as entrances The city of Surabaya, reduces and unravels the level of congestion in the city of Surabaya and increases the distribution of economic levels to the outskirts of Surabaya.

d. In an interview with the legislative body of the Regional Representative Council of the City of Surabaya (Regional Senat) gave the following answers; that the development and development of MERR and Frontage Road is to answer the challenges of the era in the expansion of the metropolis. Furthermore, the Surabaya Regional Senat acts as a mediator in the development of MERR and frontage road, as in the acquisition of land or land that has been affected by both projects.

e. Dr. Siti Nurlela - lecturer and expert of city explained that MERR and frontage road are transportation policies for the construction of new roads to break congestion in Surabaya. Whereas MERR and frontage road development also functioned to separate regular traffic with regional traffic in order to shorten travel time and minimize side barriers due to dense land use 
activities in the main road corridor. In the development of urban transportation, the development of MERR and frontage road is to encourage the integration of land use and transportation.

f. Mrs. Mutmainah (a house in Medokan), according to her, who works in the Bratang area, since the MERR road was inaugurated, the journey from home to work and vice versa is smoother and has a shorter travel time.

g. Mr. Suyanto (the house in Semampir) every day uses a motorcycle, feeling benefited from the MERR road construction. According to him, besides being smoother and shorter, MERR's development also provided economic value around the MERR area.

h. Mrs. Eny (is home in Medokan and works in the Semolowaru area). For Mrs. Eny the road MERR is very helpful for her mobility, because Mrs. Eny uses SUV every day.

i. Mas Kapuk (living in the Pepelegi area) goes to work every day in the eastern Surabaya area, with the frontage road being helped by a trip to the workplace and vice versa. According to the office boy, congestion on Ahmad Yani's road no longer occurs throughout the day, because the traffic jams only occur around 7:00 am and in the afternoon around 16.00.

j. Economically and business is also felt by some business people, both in the banking sector and entrepreneurial businesses. As felt by Mr. Surya (employee of a private bank) who is domiciled in Wage and has an office in north Surabaya, that frontage road is very helpful in traveling to the office and returning home.

\section{Conclusion}

Based on data tables and graphs as a whole researchers can conclude users of MERR and Frontage road traffic users as follows: (1) (MERR and Frontage Road users occupy the first place at the most are the types of motorized vehicles, the second is the type of private car and the third is the Truck / Pick Up / Tank Car vehicle and the General Vehicle / Yellow Plate (Passenger Transportation) and Others (Becak, Bike). Of all MERR and Frontage Road's most congested lines, Frontage Road is on the west side of Ahmad Yani. On the contrary, from all the MERR and Frontage road lines which are the quietest compared to other routes, Frontage Road on the East side of Ahmad Yani. The density seems to soar mainly on Mondays or on effective working days. This was allegedly because the go-ride application became an option as a cheap and convenient mode of transportation.(2) Whereas from the results of interviews with executive institutions of the government and legislative bodies as well as interviews with MERR and frontage road users, all showed good impression. Whereas MERR and frontage road development is very necessary for the City of Surabaya, so the development must continue to realize sustainable development.

\section{References}

[1] A. Chaedar and A., Pokoknya Kualitatif: Dasar-Dasar Merancang dan Melakukan Penelitian Kualitatif. Jakarta: Pustaka Jaya, 2011.

[2] Civil Registration Service, "Surabaya City Population Registration and Civil Registration Service," 2017. 
